\title{
Hepatitis C Virus entry: the early steps in the viral replication cycle
} Ali Sabahi

\author{
Address: Department of Microbiology and Immunology, Tulane University Health Sciences Center, New Orleans, Louisiana, USA \\ Email: Ali Sabahi - asabahi@gmail.com
}

Published: 30 July 2009

Virology Journal 2009, 6:117 doi:10.1186/1743-422X-6-117

This article is available from: http://www.virologyj.com/content/6/1/II7

(C) 2009 Sabahi; licensee BioMed Central Ltd.

This is an Open Access article distributed under the terms of the Creative Commons Attribution License (http://creativecommons.org/licenses/by/2.0), which permits unrestricted use, distribution, and reproduction in any medium, provided the original work is properly cited.
Received: 7 July 2009

Accepted: 30 July 2009

\begin{abstract}
Approximately 170 million are infected with the hepatitis $\mathrm{C}$ virus $(\mathrm{HCV})$ world wide and an estimated 2.7 million are HCV RNA positive in the United States alone. The acute phase of the $\mathrm{HCV}$ infection, in majority of individuals, is asymptomatic. A large percentage of those infected with $\mathrm{HCV}$ are unable to clear the virus and become chronically infected. The study of the HCV replication cycle was hampered due to difficulties in growing and propagating the virus in an in vitro setting. The advent of the HCV pseudo particle ( $\mathrm{HCV}$ PP) and HCV cell culture ( $\mathrm{HCV} c \mathrm{c})$ systems have made possible the study of the HCV replication cycle, in vitro. Studies utilizing the $\mathrm{HCV}_{\mathrm{pP}}$ and $\mathrm{HCV} c \mathrm{c}$ systems have increased our insight into the early steps of the viral replication cycle of HCV, such as the identification of cellular co-receptors for binding and entry. The aim of this article is to provide a review of the outstanding literature on HCV entry, specifically looking at cellular coreceptors involved and putting the data in the context of the systems used (purified viral envelope proteins, $\mathrm{HCV}_{\mathrm{PP}}$ system, $\mathrm{HCV}$ cc system and/or patient sera) and to also give a brief description of the cellular co-receptors themselves.
\end{abstract}

\section{Introduction}

\section{Epidemiology}

Approximately 170 million are infected with the hepatitis $\mathrm{C}$ virus (HCV) world wide. $\mathrm{HCV}$ is a positive strand RNA virus belonging to the flaviviridae family and is the sole member of the genus Hepacivirus. It is a hepatotropic virus which replicates in the cytoplasm of hepatocytes. In the United States an estimated 2.7 million are HCV RNA positive [1]. Most individuals infected with HCV show little or no symptoms during the acute phase of the infection. Of those infected with HCV, 54-86\% fail to clear the virus and develop a chronic infection. The chronic phase can last many decades and can ultimately lead to end stage liver disease. In retrospective studies in individuals with chronic HCV infections, cirrhosis of the liver occurred in $17-55 \%$, hepatocellular carcinoma (HCC) developed in $1-23 \%$, and liver related death occurred in $4-15 \%$. In prospective studies, cirrhosis developed in $7-16 \%$ of chronically infected individuals, HCC occurred in $0.7 \%-$ $16 \%$, and liver related death in $1.3-3.7 \%$ [2]. HCC, by itself, is the third leading cause of cancer related deaths worldwide with $40.1 \%$ of patients with HCC being antiHCV positive [3].

\section{Treatment options and efficiency}

Since the initial acute phase of a HCV infection is in most cases asymptomatic, most infected individuals seeking treatment are chronically infected. The goal of any treatment is to achieve a sustained virological response (SVR), which is the absence of serum HCV RNA up to 6 months after therapy is concluded. The initial tool for treatment for a HCV infection was mono-therapy with interferon- $\alpha$ (IFN- $\alpha$ ). An improvement was made to this therapy with the introduction of pegylated interferon- $\alpha$ (peg-IFN- $\alpha$ ). The purpose and result of the pegylation of IFN- $\alpha$ was an increase in the half life of the drug, in vivo, from a few 
hours to days. This resulted in an increase of greater than $100 \%$ in achievement of SVR when compared to treatment with IFN- $\alpha$ [4]. To increase efficiency of the treatment, peg-IFN- $\alpha$ therapy has been supplemented with ribavirin. Combination therapy with peg-IFN- $\alpha$ and ribavirin has resulted in a further increase in treatment efficiency with $54 \%$ of HCV infected patients achieving SVR.

The response and rate of SVR is dependent on the genotype of HCV with only $30 \%$ of genotype 1 infected individuals achieving SVR, whereas greater than $80 \%$ of genotype 2 or 3 achieve SVR with combination therapy [4]. Combination therapy treatment regiments are genotype dependent and the amount of peg-IFN- $\alpha$ administered is dependent on the type used. For peg-IFN- $\alpha-2 \mathrm{a}$ a dose of $180 \mu \mathrm{g} /$ week is prescribed during the course of the therapy. For peg-IFN- $\alpha-2 \mathrm{~b}$ a dose of $1.5 \mu \mathrm{g} / \mathrm{kg} /$ week is prescribed. For those infected with HCV genotypes 1, 4, 5, or 6 , peg-IFN- $\alpha$ is prescribed in combination with $1000 \mathrm{mg} /$ day (75 kg or less) or $1200 \mathrm{mg} /$ day (greater than $75 \mathrm{~kg}$ ) of ribavirin. For those infected with genotype 2 or 3 the duration of treatment is 24 weeks with the combination of peg-IFN- $\alpha$ and $800 \mathrm{mg} /$ day of ribavirin prescribed [5].

Of those that do not respond to therapy, and continue to be chronically infected, a percentage will develop HCC or decompensation and therefore require a liver transplant. For those with an active HCV infection, reinfection after transplantation is universal. Reinfection occurs during liver reperfusion with HCV levels reaching pre-transplant levels in a period of 72 hours. Post-transplantation, the steady state of HCV viral load is 10 times higher than pretransplantation. Of those that develop post-transplantation cirrhosis, 42\% develop decompensation and only $50 \%$ survive one year after the development of decompensation. Living donor liver transplant (LDLT) allows for the pre-treatment of patients, prior to the transplantation, to lower the viral load or eradicate the virus. This leads to a very low $(10 \%)$ post-transplantation viral reoccurrence [6].

\section{Genomics and Proteomics}

The hepatitis $\mathrm{C}$ virus (HCV), a positive stranded RNA virus, is the sole member of the Hepacivirus genus within the Flaviviridae family. The HCV genome is $9.6 \mathrm{~kb}$ with a 5 ' NCR, followed by an open reading frame coding for structural and non-structural proteins, and 3' NCR region. Within the 5' NCR region resides an internal ribosome entry site (IRES) which drives the translation of the genome. The product of the translation process is a 3000 amino acid long polyprotein. The polyprotein is cleaved by viral and cellular enzymes (signal peptidases) to individual proteins. The structural proteins are the core protein and the envelope glycoproteins, E1 and E2. The nonstructural proteins are the P7 ion channel, the NS2-3 pro- tease, the NS3 serine protease and RNA helicase, the NS4A polypeptide, the NS4B and NS5A proteins, and the NS5B RNA-dependent RNA polymerase (RdRp) [7].

The NS5B RdRp lacks proof reading function, and coupled with the high rate of replication of the virus, leads to the production of a viral pool with high level of genetic variability. HCV isolates are classified into genotypes and subtypes [8]. There are 6 major genotypes that differ in nucleotide sequence by $30-50 \%$ and several subtypes within a genotype that differ in nucleotide sequence by $20-25 \%$. The term quasispecies refers to the genetic heterogeneity of the viral pool found in an infected individual [8]. Of the six different genotypes, genotype 1 is the most resistant to current therapy for HCV infection.

\section{In vitro models of $\mathrm{HCV}$ infection}

Since the discovery of HCV different in vitro models have been used to study the viral replication cycle. The first in vitro system of significance was the HCV replicon system. In a prototype HCV replicon the HCV IRES drives the translation of a neomycin phosphotransferase gene followed by a heterologous (ECMV) IRES driving the translation of the HCV structural and nonstructural (full length replicon), or nonstructural genes (subgenomic replicon) [9]. The HCV replicon system allowed for the first time the study of HCV RNA replication but not the whole viral replication cycle. Cells transfected with the HCV replicon, although replicating HCV RNA at high levels, were incapable of producing infectious virus. An in vivo study in chimpanzees supported the hypothesis that the adaptive mutations required for efficient replication of the HCV genome in vitro interfered with virus packaging and secretion [10].

The HCV replicon system allowed for the study of HCV RNA replication. To understand the process of entry a HCV pseudo-particle (HCVpp) system was contrived $[11,12]$. HCVpp is made by transfecting 293 T cells with 2 plasmids, one containing an envelope deficient HIV proviral gene, with a luciferase cassette, and the second containing the HCV glycoproteins. The particles produced can then be used to infect naive cells and the level of infectivity can be measured by a luciferase assay. The HCVpp system allowed for the study of early infection events, binding and entry, of the HCV replication cycle.

In 2003 a HCV genotype 2 a clone was isolated from a Japanese patient with a rare case of fulminant hepatitis $\mathrm{C}$. This clone was designated as JFH1 (for Japanese fulminant hepatitis 1) and the replicon constructed from this strain was found to replicate in Huh-7 cells (hepatoma cell line) without the need for adaptive mutations [13]. Subsequently, it was found that transfection of JFH1 RNA into Huh7 cells resulted in the de novo production of 
infectious virus (designated HCVcc for cell culture derived HCV) that is capable of infecting naive Huh7 cells [1416]. The virus produced in tissue culture was infectious in chimpanzees [14,17] and in immunodeficient mice with partial human livers, and the virus inocula derived from these animals was infectious for naive Huh7 cells [17].

\section{HCV replication cycle}

HCV infection is a highly dynamic process with a viral half life of a few hours and production/clearance of an estimated $10^{12}$ virions per day in an infected individual [18]. Upon binding to hepatocytes, HCV enters cells by clathrin-mediated endocytosis [19]. A number of cellular coreceptors of HCV have been identified. They include glycosaminoglycans [20-24], the LDL receptor (LDLR) [25,26], DC-SIGN and L-SIGN [27-29], CD81 [24,30-47], SRBI [48-56], and claudin-1 [57-59]. Current evidence suggests that within the endosome, the low $\mathrm{pH}$ environment triggers the fusion process of the virus with the endosomal membrane and the introduction of the HCV genome into the cytoplasm [60-62].

Translation of the HCV genome is driven by the IRES located in the highly conserved 5' NCR. Initiation of translation occurs through the formation of a complex of the HCV IRES and the 40S ribosomal subunit. This event is followed by association eIF3 and the ternary complex of eIF2Met-tRNAGTP and the formation of a 48S-like complex at the initiation codon of the HCV RNA. The final and rate limiting step is the GTP-dependent association of the $60 S$ subunit to form the $80 S$ complex [63]. The translation process and subsequent processing by viral and cellular proteases yields mature structural and non-structural proteins. The structural proteins and $\mathrm{p} 7$ polypeptide are processed by the endoplasmic reticulum (ER) signal peptidase and the nonstructural protein are processed by the NS2-3 protease and NS3-4A serine protease [7].

The expression of the HCV proteins leads to the formation of replication complexes in the cytosol. The replication complexes are situated near the cell membrane which can be visualized as a membrane alteration called the membranous web [64,65]. It has been recently shown that the binding of a liver specific micro-RNA (miRNA), miRNA122, to the 5' NCR of HCV enhances the viral RNA replication process [66]. The expression of HCV proteins and the replication of the HCV genome is followed by the packaging of the virus particles and secretion. Presumably virions form by budding into the ER and exiting through the secretory pathway.

\section{HCV association with lipoproteins and particle density}

Current evidence indicates that HCV particles, both in vitro and in vivo, exist as virus-lipoprotein particles with a broad density profile [15,67-70]. The density profile of a HCV positive serum sample from a chronically infected patient displayed a distribution from $1.13-1.04 \mathrm{~g} / \mathrm{ml}$, with the majority of the HCV RNA being at $1.08 \mathrm{~g} / \mathrm{ml}$ and below. At $\mathrm{pH} 4$ the density shifted slightly toward higher densities and an increase to $\mathrm{pH} 9.2$ had no effect on the density profile. Immunoprecipitation experiments using ApoB and ApoE antibody showed that at densities below $1.06 \mathrm{~g} / \mathrm{ml}$ the HCV particles from the serum sample were associated with ApoB and ApoE, which suggests association of these viral particles with LDL and VLDL. This association decreased as particle densities increased [68].

The density profile of HCVcc particles shows an HCV RNA distribution from 1.0 to $1.18 \mathrm{~g} / \mathrm{ml}$ with a peak at 1.13 to $1.14 \mathrm{~g} / \mathrm{ml}$. The HCVcc infectivity profile displays a broad distribution from 1.01 to $1.12 \mathrm{~g} / \mathrm{ml}$ with no infectivity at densities greater the $1.12 \mathrm{~g} / \mathrm{ml}$ [15]. The HCV RNA and infectivity peaks of the density profile HCVcc do not overlap and there is little or no infectivity at the density of the RNA peak. This fraction has been shown to largely contains a RNase resistant encapsidated HCV RNA particles which are non-infectious [67].

\section{HCV entry cellular receptors CD8I}

CD81 was recognized early as an entry receptor for HCV [43]. CD81 is a member of the tetraspanin family of proteins. Tetraspanins are type III membrane glycoproteins which span the membrane 4 times and therefore producing 2 extracellular loops and a short intracellular loop. Of the 2 extracellular loop, the long extracellular loop (LEL) contains the signature structural feature of the tetraspanin family of proteins. There are disulfide bonds between the 4 cysteine residues in the LEL which form a subloop structure containing a region that is hypervariable between family members. The region outside the subloop contains greater structural conservation among family members, forming 3 alpha helices. Tetraspanins have no intrinsic enzymatic activity. They form structures on the plasma membrane called tetraspanin enriched microdomains (TEMS) which are distinct from lipid rafts although they have been shown to interact physically. Although there has been evidence that tetraspanins interact with counter receptors on other cells, most evidence indicates that they instead act in cis with other transmembrane proteins and regulate post-ligand binding events, including integrinmediated adhesion strengthening. The c-terminus of CD81, CD151, and other tetraspanins meet the criteria for being recognized by either type III or type I PDZ domains therefore leaving open the possibility of interaction with the cytoskeleton. Previous studies have shown that tetraspanins affect such processes such as cell proliferation, apoptosis, and tumor metastasis [71,72].

Due to the lack of an in vitro infectious system, early studies utilized soluble E2 (sE2, lacking the transmembrane region) to identify CD81 as a $\mathrm{HCV}$ receptor $[31,36,43,73$ - 
76]. The binding strength, $\mathrm{K}_{\mathrm{d}}$, of $\mathrm{sE2}$ to CD81 LEL were experimentally found to be at $1.8 \mathrm{nM}$ at $25^{\circ} \mathrm{C}$ and $9.1 \mathrm{nM}$ at $37^{\circ} \mathrm{C}$, and the formation of disulfide bonds among the 4 cysteines in the LEL are necessary condition for sE2 binding to the CD81 LEL [77]. The role of CD81 as a cellular receptor for $\mathrm{HCV}$ was further strengthened with the advent of the HCVpp [32,34,37,40,41,47,49,55,78] and HCVcc $[24,30,38,55]$ systems. It has been demonstrated that HCV and HCV glycoprotein E2 bind CD81 and not other members of the tetraspanin family [36]. Binding of E2 occurs at the CD81 LEL and binding of E2 to CD81, or infections with HCVpp or HCVcc, are inhibited with pretreatment with CD81 LEL or antibody versus CD81 $[34,36,47,76,77]$.

Expression of CD81 is not indicative of permissiveness to HCV infection and the expression of human CD81 in cells that are CD81 negative or in cells of other species does not confer susceptibility to HCV infection, with the exception of human CD81 expression in CD81 negative human hepatic cell lines (i.e. HepG2 cell line) [32$34,37,41,47,79]$. The level of CD81 expression does not foretell the level of permissiveness to HCV infection. HepG2 cells, a CD81 negative human hepatoma cell line, transfected and expressing CD81 were less susceptible to HCVpp infection than Huh7 cells, a CD81 positive human hepatoma cell line, although expressing higher levels of surface CD81 [34].

The identification CD81 LEL as the domain which interacts with HCV E2 led to studies to discern the E2 binding site on the LEL. It was previously shown that CD81 is normally found as a homodimer on the plasma membrane, and binding studies showed that sE2 binds optimally to a LEL dimer and with much less affinity to a LEL monomer. Furthermore, mutational studies on the LEL identified L162, I182, N184, and F186 as residues that might form part of the E2 binding site. Mutations to these residues do not disrupt the formation of CD81 multimers or the formation of disulfide bonds within the LEL [76].

Antibodies against CD81 were shown to block HCVcc infection if introduced prior to or after the binding of virus to Huh7-Lunet cells at $4^{\circ} \mathrm{C}$. In a follow up experiment, cells were infected at various duration, at $37^{\circ} \mathrm{C}$, in the presence or absence of anti-CD81, for 10, 20, 30 or 60 minutes. Subsequently, cells were washed and medium was added containing anti-CD81 for 4 hours. The cells were washed and fresh media, without anti-CD81, was added and the efficiency of HCVcc infection was compared to a control infection. Anti-CD81 was able to potently inhibit HCVcc infection, by $60 \%$, even when following an extended binding phase at $37^{\circ} \mathrm{C}$, suggesting that CD81 acts at a stage after virus binding [62].

\section{SRBI}

The class B scavenger receptor (SRBI) protein was initially identified as a high affinity low density lipoprotein (LDL) and modified LDL receptor $[80,81]$. It is a $82 \mathrm{KD}$ protein, located primarily to the caveolae, with 2 transmembrane regions, 2 cytoplasmic domains, and large extracellular loop containing a cysteine rich region and 9 putative sites for N-linked glycosylation [82-84]. Its primary function is as a high density lipoprotein (HDL) receptor and its role in cholesterol transport was clarified shortly thereafter [85-88]. SRBI is highly expressed in the liver and steroidgenic tissues, such as the adrenal gland and the ovaries $[85,86,89]$.

Central to the physiological role of SRBI is its primary ligand, HDL. HDL can accept free cholesterol and converts it to cholesterol ester (CE) by a HDL associated enzyme lecithin cholesterol acyltransferase. HDL associated CE can be transferred to other lipoproteins for subsequent transport and metabolism. HDL can deliver the CE to the liver, or steroidgenic tissues in which the CE is used for the production of steroid hormones. In the liver, the HDLderived cholesterol can be secreted into bile, converted to bile acids, or repackaged into lipoproteins and secreted [89].

The role of SRBI in cholesterol regulation is one of uptake and efflux. The process of selective uptake of free cholesterol (FC) and CE from HDL and LDL particles is largely accomplished without the breakdown of the lipoparticles $[82-85,87,88,90-92]$. The reverse process of efflux is the movement of cholesterol from the cell to HDL and LDL particles via SRBI $[84,88,93,94]$. The process of uptake and efflux of cholesterol is inhibited by antibodies against SRBI, which inhibit the binding of lipoprotein, and without an acceptor, such as HDL, there is not an observable transfer of cholesterol from SRBI expressing cells to the extracellular space $[94,95]$.

The importance of SRBI to cholesterol metabolism is further highlighted by work done with mice. In one study targeted mutation of the SRBI genes in mice lead to an increase in plasma cholesterol levels of 30-40\% in heterozygote (single knockout mutation) animals and an increase of 2.2 folds in the homozygote (double knockout mutation) as compared to wild type [96]. In a separate study, with mutations in the promoter region of SRBI, there was an increase in plasma cholesterol levels of 50$70 \%$ and an increase in size and cholesterol content of the HDL particles in mutant mice as compared to wild type. There was also a decrease in the hepatic uptake of free cholesterol (40\%) and selective uptake of HDL cholesterol (50\%) by mutant animals as compared to wild type [97]. Liver over-expression of SRBI in mice lead to 92-94\% decrease in total plasma cholesterol levels as compared to 
wild type animals. There was also a decrease in plasma phospholipids (75\%) and triglycerides (45-58\%) levels as compared to wild type animals [98].

SRBI and its ligand HDL are of significance in the early steps of HCV infection. The identification of SRBI as a HCV cellular receptor was made with HCVpp in vitro. The infection of 293T cells by HCVpp was enhanced 10 fold with the over-expression of SRBI, and SRBI anti-serum reduced HCVpp infectivity of Huh7 and CD81+ HepG2 cells in a dose dependent manner [49]. Infection of Huh7 cells by HCVpp was enhanced in the presence of HDL. The increase in infectivity was 5 fold if the HDL was added to the media after HCVpp binding to cells whereas the increase was only 1.7 fold when both were added simultaneously. This points to the possibility that HDL enhancement of HCVpp infectivity occurs post binding [50]. The production of HCVpp particles in presence of HDL or human serum increased infectivity of the produced virus in a dose dependent manner. There was not a significant increase in infectivity when the virus was grown in the presence of LDL or VLDL. The enhancement in infectivity was lost when cells were treated with antiSRBI prior to infection or SRBI expression was attenuated. Enhancement was also lost, in a dose dependent manner, upon treatment of cells with drugs which block SRBI ability to uptake cholesterol esters from HDL [51].

As with the HCVpp, similar results are seen with the $\mathrm{HCV} c \mathrm{c}$ in vitro system. Infectivity of HCVCc, grown in serum free media, increased up to 2 folds with introduction of HDL, but decreased with increasing concentrations of HDL. At HDL levels equivalent to physiological concentrations, HDL was inhibitory for HCVcc infection of Huh7 cells [99]. In a separate study, HCVcc infectivity of Huh7.5 cells over-expressing SRBI increased 18 fold as compared to parental cells. The over-expression of SRBI in Huh7.5 cells led to an increase in cell to cell spread and secondary infections by HCVcc [54].

The important roles of SRBI and HDL in HCV infection has led to a closer look at the effects cholesterol has on infectivity of HCV. The depletion of cholesterol, by $60 \%$, from Huh7 cells prior to infection with HCVcc resulted in a 6.2 fold inhibition of infectivity. Inhibition was reversed upon treatment of cells with exogenous cholesterol [55]. The cholesterol/phospholipid ratio of HCVcc was found to be 1.29 , as compared to a ratio of 0.4 and 0.42 for cell membranes of non-infected and infected cells, respectively. A decrease of HCVCc cholesterol levels led to a decrease in the infectivity of the virus [100]. These results indicate the importance in cholesterol levels to infectivity which further highlight the role SRBI plays directly and indirectly in HCV infection.
The effective interaction of the HCV glycoproteins, SRBI, and CD81 are necessary for a productive infection to occur. Experimental results have shown complex formation between HCV E2, CD81, and SRBI. Removal of one protein abrogated formation of any complex between the remaining proteins [78]. In the case of HCVcc infection, synergistic inhibition of infectivity was observed when cells were pretreated with both anti-CD81 and anti-SRBI, as compared to treatment with one antibody. The authors concluded their results point to CD81 and SRBI functioning cooperatively during the infection process. Although both CD81 and SRBI are needed for a productive HCVpp infection, there was a lack of synergy when blocking both receptors which points to a lack of cooperativity between the two receptors in a HCVpp infection [55].

\section{Claudin-I}

Claudins are transmembrane proteins involved in the formation of tight junctions. Their tetraspan transmembrane topology produces two extracellular loops, one intracellular loop, and two intracellular tails (the $\mathrm{C}$ and N-terminus). Within the family of mammalian claudins the $\mathrm{N}$ terminal is $\sim 7$ amino acids, the first extracellular loop (ECL1) is 50 amino acids, the intracellular loop 12 amino acids, the second intracellular loop (ECL2) is 25 amino acids, and the C-terminal 25-50 amino acids [101103].

A general function of claudins, in tight junction formation, is paracellular sealing. Claudin-1, $-5,-11$, and -14 knock out mice have shed light on the function of these proteins, in vivo, in the tightening of skin [104], the blood brain barrier [105], myelin sheets and Sertoli cell layers [106], and the epithelial in the inner ear [107], respectively. The distinct properties of a given tissue and its relationship to its tight junctions seem to be largely dependent on the combination of claudins that are expressed and on the manner they copolymerize $[103,108,109]$. Claudin-1 is highly expressed in the liver and is also found in other epithelial tissues [110].

Performing a cyclic lentivirus based repackaging screen of a complementary DNA library, derived from a highly permissive cell line to HCV infection, for genes that confer susceptibility to $\mathrm{HCV}$ infection to non-permissive cell lines, claudin-1 was identified as a cellular receptor for HCV [111]. Claudin-1 is expressed in all hepatoma cell lines permissive to HCVcc and HCVpp infection, except for Bel7402 [112], as well as primary hepatocytes [113]. The expression of claudin-1 in 293T cells enhanced HCVpp infection, in one study by more than a 100 fold [111] and another to the same levels as HCVpp infection of Huh7.5 cells [113]. HCVpp infection of 293T cells expressing claudin-1 was inhibited by serum from $\mathrm{HCV}^{+}$ patients, anti-CD81, and bafilomycin A1, demonstrating 
that HCVpp entry was also dependent on the envelope glycoproteins, CD81, and endosomal acidification [113]. Claudin-1 expressing 293T cells were also permissive to HCVcc infection, although efficiency of infection was 1000 folds less than Huh7 cells [111]. The overexpression of claudin-1 in cell lines permissive to HCVpp infection did not enhance infectivity [111].

HCVpp infection remained CD81 dependent even when claudin-1 was overexpressed in Hep-G2 (CD81 negative cell line, becomes susceptible to HCVpp upon expression of CD81) cell line. The expression of murine claudin-1, instead of human claudin-1, did not negatively effect HCVpp susceptibility which suggests that claudin-1 in not a determinant of specie host range of the virus. Down regulation of claudin-1 via siRNA resulted in a decrease in infection levels of HCVpp and HCVcc [111].

The n-terminal $1 / 3$ of extracellular loop 1 (ECL1) was identified as sufficient for HCVpp entry when expressed in a claudin-7 background. Of the 5 residues that differ between the claudin-1 and claudin-7 in the n-terminal 1/ 3 of ECL1, 2 were found to be important in regard to HCVpp infection. The introduction of M32I or K48E into claudin-7 rendered $293 \mathrm{~T}$ cells partially permissive to HCVpp infection, but the combination of both mutations supported HCVpp entry as efficiently as claudin-1 [111].

Post binding antibody inhibition of claudin-1 demonstrate that, like CD81 [62], claudin-1 acts at a post-binding stage in HCV infection. The results of these experiments suggest a sequence in which CD81 interacts with the virus prior to claudin-1 [111]. Cell to cell fusion studies also demonstrated that claudin-1 is required for HCV envelope glycoprotein mediated fusion although it is unclear if claudin-1 participates directly in the fusion process or that its involvement is required in an earlier step [111].

Two other family members of claudin- -1 , claudin- 6 and -9 , have been identified as possible HCV cellular receptors. The expression of claudin- 6 and -9 in 293T cells resulted in the cells becoming permissive to HCVpp infection at similar levels as Huh7.5 [112,113] and permissive to HCVcc infection, but at titers 400 times lower than those achieved in Huh7.5 cells [112]. Interestingly, the attenuation of claudin- 1 expression and expression of either claudin-6 or -9 in Huh7.5 cells, lead to abrogation of HCVcc permissiveness. Furthermore the expression of claudin- 6 and -9 in claudin-1 negative hepatoma cell lines was not effective in conferring the ability to become HCVpp permissive, but the expression of claudin-1 made the cell line permissive to HCVpp infection [113]. The exception seems to be the HCVpp permissive hepatoma cell line Bel7402, which is claudin-1 negative but expresses claudin-9. The reduction in claudin-9 expression in Bel7402 led to the a significant decrease in HCVpp infectivity [112].

\section{LDLR}

The LDL receptor (LDLR) is a single pass transmembrane glycoprotein of 839 amino acids. It is a modular proteins consisting of seven adjacent LDL receptor type-A (LA) modules at the $\mathrm{n}$ terminal end, followed by a region of homology to the epidermal growth factor precursor (EGFP) which consists of two epidermal growth factorlike (EGF) modules, a YWTD domain, a third EGF module, a serine and threonine rich region, a transmembrane region, and a 50 residue cytoplasmic tail [114-116].

The LDLR receptor is responsible for the cellular sequestering of cholesterol containing LDL and VLDL particles from circulation. The underlying genetic cause familial hypercholesterolemia (FH) is a loss of function mutations in the LDLR gene. FH is an autosomal genetic disorder affecting approximately 1 in 500 individuals worldwide. In heterozygous individuals, FH presents as an increased risk of atherosclerosis and coronary heart disease. Homozygous individuals, if untreated, typically die of heart disease at an early age [116]. The LA repeats have been shown to be the ligand binding domain of LDLR [117].

A majority of plasma cholesterol in humans circulates in the form of LDL. LDL is the primary ligand for the LDLR and consists of one copy of apolipoprotein B-100 (apoB$100)$ as its primary protein component. The LDLR receptor also binds, with high affinity, lipoproteins which contain multiple copies of apolipoprotein E (apoE), such as the $\beta$-migrating forms of very low density lipoprotein $(\beta$ VLDL) and some intermediate density lipoproteins $[118,119]$. LDLR binding of apoE requires apoE association with lipids [120]. LDLR-ligand complexes enter cells via clathrin-coated pits and are then delivered to endosomes where the low $\mathrm{pH}$ environment triggers the release of ligand from receptor. The receptor is then returned to the plasma membrane in a process called receptor recycling. The lipoprotein particle proceeds to the lysosome where the hydrolysis of the released cholesterol esters occurs [121].

There is evidence that LDLR is involved in the HCV infection process. The binding of HCV particles, from HCV positive serum of patients, to human dermal fibroblasts were inhibited by pretreatment of cells with $>200 \mu \mathrm{g} / \mathrm{ml}$ of purified LDL. The expression of LDLR on COS-7 cells led to HCV binding to the cells from 7 out of 12 patient sera [25]. Further evidence for the role of LDLR in HCV infection was gathered by studies done with primary human hepatocytes. A peptide inhibitor of LDL binding to LDLR inhibited HCV infection of hepatocytes. This effect was most potent when the peptide was added at the 
time of infection and the inhibitory effect diminished progressively when peptide was added at time points after infection. This results suggests that LDLR is involved in viral attachment to the hepatocytes. Treatment of hepatocytes with monoclonal antibodies against LDLR or LDL also inhibited HCV infection [26]. These findings and the association of HCV particles with lipoproteins suggest a role for LDLR as a cellular receptor for HCV.

\section{Glycosaminoglycans}

Glycosaminoglycan (GAG) chains on cell surface proteoglycans serve as attachment sites for the binding of a number of viruses and other microorganisms. GAG chains are ubiquitously present on the cell surface of eukaryotic cells with varying composition and concentration dependent on cell type [122]. The GAG heparan sulfate comprises of a family of linear polysaccharides with a signature motif of repeating units of [GlcA-GlcNAc ${ }_{n^{\prime}}$ where GlcA is glucuronic acid and GlcNAc in N-acetylglucosamine. The saccharides undergo $\mathrm{N}$ deacetylation and $\mathrm{N}$ sulfation of the GlcNAc residues, $\mathrm{O}$ sulfation at other positions, and epimerization of GlcA to iduronic acid, which gives rise to structural diversity throughout the length of each chain [123].

The GAG heparan sulfate has been identified as a HCV cellular receptor $[20,22-24,62]$. Heparin, a close structural homologue of highly sulfated heparan sulfate, was able to bind HCV E2 in an ELISA, in a concentration-dependent manner. The dissociation constant, $\mathrm{K}_{\mathrm{d}}$, for $\mathrm{E} 2$ and $\mathrm{E} 1$ binding to heparin was measured at $5.2 \times 10^{-9} \mathrm{M}$ and 5.3 $\times 10^{-8} \mathrm{M}$, respectively $[20,22]$. The binding of E2 to HepG2 cells was inhibited in a dose-dependent manner by pre-incubation of E2 with heparin and liver derived highly sulfated heparan sulfate [20].

The pretreatment of HCVpp with heparin and highly sulfated heparan sulfate led to marked inhibition in infectivity of Huh7 cells with an $\mathrm{IC}_{50} 0.5 \mu \mathrm{g} / \mathrm{ml}$. If HCVpp was allowed to bind Huh7 cells prior to the addition of heparin or highly sulfated heparan sulfate, the inhibitory effect was not as dramatic $[22,23]$. The pretreatment of HCVcc particles with heparin led to a dose dependent inhibition of HCVcc binding at $4{ }^{\circ} \mathrm{C}$ to Huh7 cells, and the pretreatment of Huh7 cells with heparinase II and heparinase III inhibited HCVcc binding to Huh7 cells at $4{ }^{\circ} \mathrm{C}$ by $51-75 \%$ and $60-75 \%$, respectively [24].

The incubation of HCVcc particles with heparin led to a moderate dose dependent inhibition of HCVcc infection of Huh7 cells with an $\mathrm{IC}_{50}$ value of $50 \mu \mathrm{g} / \mathrm{ml}$. This inhibitory effect was not observed if Huh7 cells were pre-treated with heparin prior to the addition of virus implying direct interaction of HCVcc with heparin is responsible for the inhibition observed. The pretreatment of Huh7 cells with heparinase I and III also led to a moderate inhibition of
HCVcc infectivity (40-60\%). Heparin's inhibitory effect on HCVcc infection of Huh7 cells was abrogated if administered to cells after viral binding had taken place [62]. This, and other findings, indicate that cellular GAG, and specifically highly sulfated heparan sulfates, are involved in the process of HCV binding to cells.

\section{Occludin}

A recent study has identified occludin (OCLN) as a HCV cellular receptor [124]. OCLN is a four transmembrane domain protein present in the tight junctions of polarized epithelial cells. HCV permissive human hepatoma cell lines such as Huh7 or cell lines shown to lack other entry factors (i.e. HepG2 and 293T cells) were found to express detectable levels of OCLN. Overexpression of OCLN did not enhance susceptibility to HCVpp infection. Silencing of OCLN expression lead to inhibition of HCVpp infection in Hер3B cells and inhibition of infection of both HCVpp and HCVcc in Huh-7.5 cells. These observations indicate that OCLN is essential for HCV infection of naturally permissive cell lines. Overexpression of human OCLN in HCV resistant cell lines, which express the other entry co-receptors, led specific enhancement in susceptibility to HCVpp infection.

\section{Liver tissue expression of HCV receptors}

The expression levels and localization of the known HCV receptors in normal and infected liver was examined and published by Dr. McKeating's laboratory [125]. In a normal liver, CD81 expression on hepatocytes was observed on the basolateral surface with some canalicular expression. CD81 expression was also present in the stroma of the portal tracts. SRBI expression was seen on the sinusoidal endothelium and hepatocytes. There was minimal amount of SRBI expression observed on the bile ducts and hepatocyte expression was located at the basolateral surface. Claudin 1 expression was seen on the bile ducts and hepatocytes, with low levels of expression on the sinusoidal endothelium. Hepatocyte expression of claudin 1 was observed on the basolateral and canalicular membranes. In a HCV infected liver an increase in claudin 1 expression was observed on the basolateral membrane of hepatocytes. In normal liver tissue, the co-localization of claudin 1 and CD81 was observed to be the strongest in the apicalcanalicular region. In HCV infected liver tissue, the colocalization was prominently observed at the basolateral region. Claudin 1 and SRBI co-localization was seen at the basolateral membrane in both normal and HCV infected liver tissue.

\section{Conclusion}

This review summarizes the role each HCV cellular coreceptor in the infection process and the endogenous function of each of these co-receptors. Much has been learned in the past few years of the mechanism and requirements for HCV to successfully infect naïve cells. 
With future advances in developing robust in vivo (i.e. small animal model of HCV infection) and in vitro (i.e. infection of primary hepatocytes, HCVcc strains of different genotypes) assays our understanding of the processes involved in the early steps of HCV infection will be greatly expanded.

\section{Competing interests}

The author declares that they have no competing interests.

\section{Authors' contributions}

AS is the sole author of this manuscript.

\section{Author information}

After finishing high school in Tucson, Arizona, the author enlisted as an infantryman in the United States Army. After three years of military service, he attended Southern University in Baton Rouge, Louisiana, where he earned a bachelor of science degree in physics. He then enrolled for 2 years as a graduate student at the chemistry department at Tulane University after which he joined the Molecular and Cellular Biology Program at Tulane University Medical Center and the joined the laboratory of Dr. Robert F. Garry in 2003 and began his work on the hepatitis $C$ virus. The author successfully defended his dissertation in December of 2008.

\section{Acknowledgements}

I would like to thank my Ph.D. advisor Dr. Robert F. Garry for his guidance and support. I am also grateful for the guidance I received from my committee members Drs. William C. Wimley, Thomas G. Voss, Aline B. Scandurro, and Erik Flemington.

\section{References}

I. Alter MJ, Kruszon-Moran D, Nainan OV, McQuillan GM, Gao F, Moyer LA, Kaslow RA, Margolis HS: The prevalence of hepatitis $\mathrm{C}$ virus infection in the United States, 1988 through 1994. N Engl J Med I 999, 34 I:556-562.

2. Seeff LB: Natural history of chronic hepatitis C. Hepatology 2002, 36:S35-46

3. Levrero M: Viral hepatitis and liver cancer: the case of hepatitis C. Oncogene 2006, 25:3834-3847.

4. Di Bisceglie AM, Hoofnagle JH: Optimal therapy of hepatitis C. Hepatology 2002, 36:SI2I-7.

5. Hoofnagle JH, Seeff LB: Peginterferon and ribavirin for chronic hepatitis C. N Engl J Med 2006, 355:2444-245I.

6. Brown RS: Hepatitis C and liver transplantation. Nature 2005, 436:973-978.

7. Moradpour D, Penin F, Rice CM: Replication of hepatitis C virus. Nat Rev Microbiol 2007, 5:453-463.

8. Simmonds P, Bukh J, Combet C, Deleage G, Enomoto N, Feinstone S, Halfon P, Inchauspe G, Kuiken C, Maertens G, Mizokami M, Murphy DG, Okamoto H, Pawlotsky JM, Penin F, Sablon E, Shin-I T, Stuyver LJ, Thiel HJ, Viazov S, Weiner AJ, Widell A: Consensus proposals for a unified system of nomenclature of hepatitis $\mathbf{C}$ virus genotypes. Hepatology 2005, 42:962-973.

9. Lohmann V, Korner F, Koch J, Herian U, Theilmann L, Bartenschlager $\mathrm{R}$ : Replication of subgenomic hepatitis $C$ virus RNAs in a hepatoma cell line. Science 1999, 285: I I0-II3.

10. Bukh J, Pietschmann T, Lohmann V, Krieger N, Faulk K, Engle RE, Govindarajan S, Shapiro M, St Claire M, Bartenschlager R: Mutations that permit efficient replication of hepatitis $C$ virus RNA in Huh-7 cells prevent productive replication in chimpanzees. Proc Natl Acad Sci USA 2002, 99: | 44 I 6- | 442 I.
II. Bartosch B, Dubuisson J, Cosset FL: Infectious hepatitis C virus pseudo-particles containing functional EI-E2 envelope protein complexes. J Exp Med 2003, 1 97:633-642.

12. Flint M, Logvinoff C, Rice CM, McKeating JA: Characterization of infectious retroviral pseudotype particles bearing hepatitis C virus glycoproteins. J Virol 2004, 78:6875-6882.

13. Kato T, Date T, Miyamoto M, Furusaka A, Tokushige K, Mizokami M, Wakita T: Efficient replication of the genotype $2 \mathbf{a}$ hepatitis $\mathbf{C}$ virus subgenomic replicon. Gastroenterology 2003, 125:1808-1817.

14. Wakita T, Pietschmann T, Kato T, Date T, Miyamoto M, Zhao Z, Murthy K, Habermann A, Krausslich HG, Mizokami M, Bartenschlager $R$, Liang TJ: Production of infectious hepatitis $\mathbf{C}$ virus in tissue culture from a cloned viral genome. Nat Med 2005, I I:79|-796.

15. Lindenbach BD, Evans MJ, Syder AJ, Wolk B, Tellinghuisen TL, Liu CC, Maruyama T, Hynes RO, Burton DR, McKeating JA, Rice CM: Complete replication of hepatitis $\mathbf{C}$ virus in cell culture. Science 2005, 309:623-626.

16. Zhong J, Gastaminza P, Cheng G, Kapadia S, Kato T, Burton DR, Wieland SF, Uprichard SL, Wakita T, Chisari FV: Robust hepatitis C virus infection in vitro. Proc Natl Acad Sci USA 2005 I 02:9294-9299.

17. Lindenbach BD, Meuleman P, Ploss A, Vanwolleghem T, Syder AJ, McKeating JA, Lanford RE, Feinstone SM, Major ME, Leroux-Roels G, Rice CM: Cell culture-grown hepatitis $\mathbf{C}$ virus is infectious in vivo and can be recultured in vitro. Proc Natl Acad Sci USA 2006, 1 03:3805-3809.

18. Neumann AU, Lam NP, Dahari H, Gretch DR, Wiley TE, Layden T], Perelson AS: Hepatitis $C$ viral dynamics in vivo and the antiviral efficacy of interferon-alpha therapy. Science 1998 , 282: $103-107$

19. Blanchard E, Belouzard S, Goueslain L, Wakita T, Dubuisson J, Wychowski C, Rouille Y: Hepatitis $\mathbf{C}$ virus entry depends on clathrin-mediated endocytosis. J Virol 2006, 80:6964-6972.

20. Barth H, Schafer C, Adah MI, Zhang F, Linhardt RJ, Toyoda H, Kinoshita-Toyoda A, Toida T, Van Kuppevelt TH, Depla E, Von Weizsacker F, Blum HE, Baumert TF: Cellular binding of hepatitis $\mathbf{C}$ virus envelope glycoprotein E2 requires cell surface heparan sulfate. J Biol Chem 2003, 278:4 I003-4I0I2.

21. Goffard A, Callens N, Bartosch B, Wychowski C, Cosset FL, Montpellier C, Dubuisson J: Role of $\mathbf{N}$-linked glycans in the functions of hepatitis C virus envelope glycoproteins. J Virol 2005, 79:8400-8409.

22. Barth H, Schnober EK, Zhang F, Linhardt RJ, Depla E, Boson B, Cosset FL, Patel AH, Blum HE, Baumert TF: Viral and cellular determinants of the hepatitis $C$ virus envelope-heparan sulfate interaction. J Virol 2006, 80:10579-10590.

23. Basu A, Kanda T, Beyene A, Saito K, Meyer K, Ray R: Sulfated homologues of heparin inhibit hepatitis $C$ virus entry into mammalian cells. J Virol 2007, 81:3933-394 I.

24. Morikawa K, Zhao Z, Date T, Miyamoto M, Murayama A, Akazawa D, Tanabe J, Sone S, Wakita T: The roles of CD8I and glycosaminoglycans in the adsorption and uptake of infectious HCV particles. J Med Virol 2007, 79:7|4-723.

25. Monazahian M, Bohme I, Bonk S, Koch A, Scholz C, Grethe S, Thomssen R: Low density lipoprotein receptor as a candidate receptor for hepatitis C virus. J Med Virol 1999, 57:223-229.

26. Molina S, Castet V, Fournier-Wirth C, Pichard-Garcia L, Avner R Harats D, Roitelman J, Barbaras R, Graber P, Ghersa P, Smolarsky M, Funaro A, Malavasi F, Larrey D, Coste J, Fabre JM, Sa-Cunha A, Maurel $P$ : The low-density lipoprotein receptor plays a role in the infection of primary human hepatocytes by hepatitis $\mathbf{C}$ virus. J Hepatol 2007, 46:4I I-4I9.

27. Gardner JP, Durso RJ, Arrigale RR, Donovan GP, Maddon PJ, Dragic T, Olson WC: L-SIGN (CD 209L) is a liver-specific capture receptor for hepatitis C virus. Proc Natl Acad Sci USA 2003, 1 00:4498-4503.

28. Lozach PY, Lortat-Jacob H, de Lacroix de Lavalette A, Staropoli I, Foung S, Amara A, Houles C, Fieschi F, Schwartz O, Virelizier JL, Arenzana-Seisdedos F, Altmeyer R: DC-SIGN and L-SIGN are high affinity binding receptors for hepatitis $\mathbf{C}$ virus glycoprotein E2. J Biol Chem 2003, 278:20358-20366.

29. Cormier EG, Durso RJ, Tsamis F, Boussemart L, Manix C, Olson WC, Gardner JP, Dragic T: L-SIGN (CD209L) and DC-SIGN (CD209) mediate transinfection of liver cells by hepatitis $C$ virus. Proc Natl Acad Sci USA 2004, I 0 I:| 4067-I4072. 
30. Akazawa D, Date T, Morikawa K, Murayama A, Miyamoto M, Kaga M, Barth $\mathrm{H}$, Baumert TF, Dubuisson J, Wakita T: CD8I expression is important for the permissiveness of Huh7 cell clones for heterogeneous hepatitis C virus infection. J Virol 2007, 81:5036-5045.

31. Allander T, Forns X, Emerson SU, Purcell RH, Bukh J: Hepatitis C virus envelope protein E2 binds to CD8 I of tamarins. Virology 2000, 277:358-367.

32. Bertaux C, Dragic T: Different domains of CD8 I mediate distinct stages of hepatitis C virus pseudoparticle entry. J Virol 2006, 80:4940-4948.

33. Cocquerel L, Kuo CC, Dubuisson J, Levy S: CD8 I-dependent binding of hepatitis C virus EIE2 heterodimers. J Virol 2003, 77:10677-10683

34. Cormier EG, Tsamis F, Kajumo F, Durso RJ, Gardner JP, Dragic T: CD8I is an entry coreceptor for hepatitis C virus. Proc Natl Acad Sci USA 2004, I $01: 7270-7274$.

35. Falkowska E, Kajumo F, Garcia E, Reinus J, Dragic T: Hepatitis C virus envelope glycoprotein E2 glycans modulate entry, CD8 I binding, and neutralization. J Virol 2007, 81:8072-8079.

36. Flint M, Maidens C, Loomis-Price LD, Shotton C, Dubuisson J, Monk P, Higginbottom A, Levy S, McKeating JA: Characterization of hepatitis C virus E2 glycoprotein interaction with a putative cellular receptor, CD8 I. J Virol 1999, 73:6235-6244.

37. Flint M, von Hahn T, Zhang J, Farquhar M, Jones CT, Balfe P, Rice CM, McKeating JA: Diverse CD8 I proteins support hepatitis $\mathbf{C}$ virus infection. J Virol 2006, 80: I|33|-|||342.

38. Koutsoudakis G, Herrmann E, Kallis S, Bartenschlager R, Pietschmann $T$ : The level of CD8 I cell surface expression is a key determinant for productive entry of hepatitis $C$ virus into host cells. J Virol 2007, 81:588-598.

39. Kronenberger B, Sarrazin C, Hofmann WP, von Wagner M, Herrmann E, Welsch C, Elez R, Ruster B, Piiper A, Zeuzem S: Mutations in the putative HCV-E2 CD8I binding regions and correlation with cell surface CD8I expression. J Viral Hepat 2004, II:310-318.

40. Lavillette D, Tarr AW, Voisset C, Donot P, Bartosch B, Bain C, Patel $\mathrm{AH}$, Dubuisson J, Ball JK, Cosset FL: Characterization of hostrange and cell entry properties of the major genotypes and subtypes of hepatitis C virus. Hepatology 2005, 41:265-274.

41. McKeating JA, Zhang LQ, Logvinoff C, Flint M, Zhang J, Yu J, Butera $D$, Ho DD, Dustin LB, Rice CM, Balfe P: Diverse hepatitis C virus glycoproteins mediate viral infection in a CD8I-dependent manner. J Virol 2004, 78:8496-8505

42. Molina S, Castet V Pichard-Garcia L, Wychowski C Meurs E, Pascussi JM, Sureau C, Fabre JM, Sacunha A, Larrey D, Dubuisson J, Coste J, McKeating J, Maurel P, Fournier-Wirth C: Serum-derived hepatitis C virus infection of primary human hepatocytes is tetraspanin CD8 I dependent. J Virol 2008, 82:569-574.

43. Pileri P, Uematsu $Y$, Campagnoli $S$, Galli G, Falugi $F$, Petracca $R$ Weiner AJ, Houghton M, Rosa D, Grandi G, Abrignani S: Binding of hepatitis C virus to CD8I. Science I998, 282:938-94I.

44. Sasaki M, Yamauchi K, Nakanishi T, Kamogawa Y, Hayashi N: In vitro binding of hepatitis $C$ virus to CD8I-positive and -negative human cell lines. J Gastroenterol Hepatol 2003, I 8:74-79.

45. Tan YJ, Lim SP, Ng P, Goh PY, Lim SG, Tan YH, Hong W: CD8 I engineered with endocytotic signals mediates HCV cell entry: implications for receptor usage by HCV in vivo. Virology 2003 308:250-269.

46. Voisset C, Lavie M, Helle F, Op De Beeck A, Bilheu A, BertrandMichel J, Terce F, Cocquerel L, Wychowski C, Vu-Dac N, Dubuisson J: Ceramide enrichment of the plasma membrane induces CD8 I internalization and inhibits hepatitis C virus entry. Cell Microbiol 2008, 10:606-617.

47. Zhang J, Randall G, Higginbottom A, Monk P, Rice CM, McKeating JA: $C D 8 I$ is required for hepatitis $C$ virus glycoprotein-mediated viral infection. J Virol 2004, 78: | 448- | 455.

48. Scarselli E, Ansuini H, Cerino R, Roccasecca RM, Acali S, Filocamo G, Traboni C, Nicosia A, Cortese R, Vitelli A: The human scavenger receptor class $B$ type $I$ is a novel candidate receptor for the hepatitis C virus. EMBO J 2002, $21: 5017-5025$.

49. Bartosch B, Vitelli A, Granier C, Goujon C, Dubuisson J, Pascale S, Scarselli E, Cortese R, Nicosia A, Cosset FL: Cell entry of hepatitis $C$ virus requires a set of co-receptors that include the CD8I tetraspanin and the SR-B I scavenger receptor. J Biol Chem 2003, 278:41624-41630.
50. Voisset C, Callens N, Blanchard E, Op De Beeck A, Dubuisson J, VuDac N: High density lipoproteins facilitate hepatitis $C$ virus entry through the scavenger receptor class B type I. J Biol Chem 2005, 280:7793-7799.

5I. Bartosch B, Verney G, Dreux M, Donot P, Morice Y, Penin F, Pawlotsky JM, Lavillette $D$, Cosset FL: An interplay between hypervariable region I of the hepatitis $\mathrm{C}$ virus E2 glycoprotein, the scavenger receptor $\mathrm{BI}$, and high-density lipoprotein promotes both enhancement of infection and protection against neutralizing antibodies. J Virol 2005, 79:82 17-8229.

52. Maillard P, Huby T, Andreo U, Moreau M, Chapman J, Budkowska A: The interaction of natural hepatitis $C$ virus with human scavenger receptor SR-BI/Cla I is mediated by ApoB-containing lipoproteins. FASEB J 2006, 20:735-737.

53. Zeisel MB, Koutsoudakis G, Schnober EK, Haberstroh A, Blum HE, Cosset FL, Wakita T, Jaeck D, Doffoel M, Royer C, Soulier E, Schvoerer E, Schuster C, Stoll-Keller F, Bartenschlager R, Pietschmann T, Barth $\mathrm{H}$, Baumert TF: Scavenger receptor class B type $\mathbf{I}$ is a key host factor for hepatitis $\mathbf{C}$ virus infection required for an entry step closely linked to CD8I. Hepatology 2007 , 46: $1722-173 \mid$.

54. Grove J, Huby T, Stamataki Z, Vanwolleghem T, Meuleman P, Farquhar M, Schwarz A, Moreau M, Owen JS, Leroux-Roels G, Balfe P, McKeating JA: Scavenger receptor BI and BII expression levels modulate hepatitis C virus infectivity. J Virol 2007, 81:3162-3169.

55. Kapadia SB, Barth H, Baumert T, McKeating JA, Chisari FV: Initiation of hepatitis $C$ virus infection is dependent on cholesterol and cooperativity between CD8 I and scavenger receptor B type I. J Virol 2007, 8 I:374-383.

56. Grove J, Nielsen S, Zhong J, Bassendine MF, Drummer HE, Balfe P, McKeating JA: Identification of a residue in hepatitis $C$ virus $E 2$ glycoprotein that determines scavenger receptor $\mathrm{BI}$ and CD8I receptor dependency and sensitivity to neutralizing antibodies. J Virol 2008.

57. Mee CJ, Grove J, Harris HJ, Hu K, Balfe P, McKeating JA: Effect of cell polarization on hepatitis C virus entry. J Virol 2008, 82:46I-470.

58. Farquhar MJ, Harris HJ, Diskar M, Jones S, Mee CJ, Nielsen SU, Brimacombe CL, Molina S, Toms GL, Maurel P, Howl J, Herberg FW, van ljzendoorn SC, Balfe P, McKeating JA: Protein Kinase A dependent step(s) in Hepatitis C virus entry and infectivity. J Virol 2008

59. Harris HJ, Farquhar MJ, Mee CJ, Davis C, Reynolds GM, Jennings A, Hu K, Yuan F, Deng H, Hubscher SG, Han JH, Balfe P, McKeating JA: CD8 I and claudin I coreceptor association: role in hepatitis C virus entry. J Virol 2008, 82:5007-5020.

60. Lavillette D, Bartosch B, Nourrisson D, Verney G, Cosset FL, Penin F, Pecheur El: Hepatitis C virus glycoproteins mediate low pHdependent membrane fusion with liposomes. J Biol Chem 2006 , 28 I:3909-39I7.

61. Tscherne DM, Jones CT, Evans MJ, Lindenbach BD, McKeating JA, Rice CM: Time- and temperature-dependent activation of hepatitis C virus for low-pH-triggered entry. J Virol 2006, 80:1734-174I.

62. Koutsoudakis G, Kaul A, Steinmann E, Kallis S, Lohmann V, Pietschmann T, Bartenschlager R: Characterization of the early steps of hepatitis $C$ virus infection by using luciferase reporter viruses. J Virol 2006, 80:5308-5320.

63. Otto GA, Puglisi JD: The pathway of HCV IRES-mediated translation initiation. Cell 2004, I 19:369-380.

64. Moradpour D, Gosert R, Egger D, Penin F, Blum HE, Bienz K: Membrane association of hepatitis $C$ virus nonstructural proteins and identification of the membrane alteration that harbors the viral replication complex. Antiviral Res 2003, 60:103-109.

65. Gosert R, Egger D, Lohmann V, Bartenschlager R, Blum HE, Bienz K, Moradpour D: Identification of the hepatitis $C$ virus RNA replication complex in Huh-7 cells harboring subgenomic replicons. J Virol 2003, 77:5487-5492.

66. Jopling CL, Yi M, Lancaster AM, Lemon SM, Sarnow P: Modulation of hepatitis $C$ virus RNA abundance by a liver-specific MicroRNA. Science 2005, 309: 1577-I58I.

67. Gastaminza P, Kapadia SB, Chisari FV: Differential biophysical properties of infectious intracellular and secreted hepatitis C virus particles. J Virol 2006, 80: I | 074- I I08।. 
68. Nielsen SU, Bassendine MF, Burt AD, Martin C, Pumeechockchai W, Toms GL: Association between hepatitis $C$ virus and verylow-density lipoprotein (VLDL)/LDL analyzed in iodixanol density gradients. J Virol 2006, 80:2418-2428.

69. Pumeechockchai W, Bevitt D, Agarwal K, Petropoulou T, Langer BC, Belohradsky B, Bassendine MF, Toms GL: Hepatitis C virus particles of different density in the blood of chronically infected immunocompetent and immunodeficient patients: Implications for virus clearance by antibody. J Med Virol 2002, 68:335-342.

70. Andre P, Komurian-Pradel F, Deforges S, Perret M, Berland JL, Sodoyer M, Pol S, Brechot C, Paranhos-Baccala G, Lotteau V: Characterization of low- and very-low-density hepatitis $C$ virus RNA-containing particles. J Virol 2002, 76:6919-6928.

7I. Martin F, Roth DM, Jans DA, Pouton CW, Partridge LJ, Monk PN, Moseley GW: Tetraspanins in viral infections: a fundamental role in viral biology? J Virol 2005, 79: 10839-1085।

72. Hemler ME: Tetraspanin functions and associated microdomains. Nat Rev Mol Cell Biol 2005, 6:80I-8II.

73. Higginbottom A, Quinn ER, Kuo CC, Flint M, Wilson LH, Bianchi E, Nicosia A, Monk PN, McKeating JA, Levy S: Identification of amino acid residues in CD8 I critical for interaction with hepatitis C virus envelope glycoprotein E2. IVirol 2000, 74:3642-3649.

74. Meola A, Sbardellati A, Bruni Ercole B, Cerretani M, Pezzanera M Ceccacci A, Vitelli A, Levy S, Nicosia A, Traboni C, McKeating J, Scarselli E: Binding of hepatitis C virus E2 glycoprotein to CD8I does not correlate with species permissiveness to infection. J Virol 2000, 74:5933-5938.

75. Masciopinto F, Campagnoli S, Abrignani S, Uematsu Y, Pileri P: The small extracellular loop of CD8I is necessary for optimal surface expression of the large loop, a putative $\mathrm{HCV}$ receptor. Virus Res 200I, 80: I-I0.

76. Drummer HE, Wilson KA, Poumbourios P: Identification of the hepatitis C virus E2 glycoprotein binding site on the large extracellular loop of CD8 I. J Virol 2002, 76: I I I43-I I I47.

77. Petracca R, Falugi F, Galli G, Norais N, Rosa D, Campagnoli S, Burgio V, Di Stasio E, Giardina B, Houghton M, Abrignani S, Grandi G: Structure-function analysis of hepatitis C virus envelope-CD8 I binding. J Virol 2000, 74:4824-4830.

78. Heo TH, Lee SM, Bartosch B, Cosset FL, Kang CY: Hepatitis C virus E2 links soluble human CD8 I and SR-B I protein. Virus Res 2006, I 2 I:58-64.

79. Masciopinto F, Freer G, Burgio VL, Levy S, Galli-Stampino L, Bendinelli $M$, Houghton M, Abrignani S, Uematsu $Y$ : Expression of human CD8 I in transgenic mice does not confer susceptibility to hepatitis C virus infection. Virology 2002, 304:187-196.

80. Acton SL, Scherer PE, Lodish HF, Krieger M: Expression cloning of SR-BI, a CD36-related class B scavenger receptor. J Biol Chem 1994, 269:21003-21009.

81. Rigotti A, Acton SL, Krieger M: The class B scavenger receptors SR-BI and CD36 are receptors for anionic phospholipids. J Biol Chem 1995, 270:1622I-16224.

82. Connelly MA, Klein SM, Azhar S, Abumrad NA, Williams DL: Comparison of class $B$ scavenger receptors, CD36 and scavenger receptor $\mathrm{BI}$ (SR-BI), shows that both receptors mediate high density lipoprotein-cholesteryl ester selective uptake but SR-BI exhibits a unique enhancement of cholesteryl ester uptake. J Biol Chem 1999, 274:4|-47.

83. Babitt J, Trigatti B, Rigotti A, Smart EJ, Anderson RG, Xu S, Krieger M: Murine SR-BI, a high density lipoprotein receptor that mediates selective lipid uptake, is $\mathbf{N}$-glycosylated and fatty acylated and colocalizes with plasma membrane caveolae. Biol Chem 1997, 272: 13242-13249.

84. Webb NR, Connell PM, Graf GA, Smart EJ, de Villiers WJ, de Beer FC, Westhuyzen DR van der: SR-BII, an isoform of the scavenger receptor $\mathrm{BI}$ containing an alternate cytoplasmic tail, mediates lipid transfer between high density lipoprotein and cells. J Biol Chem 1998, 273:1524I-15248.

85. Acton S, Rigotti A, Landschulz KT, Xu S, Hobbs HH, Krieger M: Identification of scavenger receptor SR-BI as a high density lipoprotein receptor. Science 1996, 271:5।8-520.

86. Landschulz KT, Pathak RK, Rigotti A, Krieger M, Hobbs HH: Regulation of scavenger receptor, class $B$, type $I$, a high density lipoprotein receptor, in liver and steroidogenic tissues of the rat. J Clin Invest 1996, 98:984-995.
87. Murao K, Terpstra V, Green SR, Kondratenko N, Steinberg D, Quehenberger O: Characterization of CLA-I, a human homologue of rodent scavenger receptor $\mathrm{BI}$, as a receptor for high density lipoprotein and apoptotic thymocytes. J Biol Chem 1997, 272: $1755 \mid-17557$.

88. Ji $Y$, Jian B, Wang N, Sun $Y$, Moya ML, Phillips MC, Rothblat GH, Swaney JB, Tall AR: Scavenger receptor BI promotes high density lipoprotein-mediated cellular cholesterol efflux. J Biol Chem 1997, 272:20982-20985.

89. Trigatti BL, Rigotti A, Braun A: Cellular and physiological roles of SR-BI, a lipoprotein receptor which mediates selective lipid uptake. Biochim Biophys Acta 2000, 1529:276-286.

90. Gu X, Trigatti B, Xu S, Acton S, Babitt J, Krieger M: The efficient cellular uptake of high density lipoprotein lipids via scavenger receptor class B type I requires not only receptor-mediated surface binding but also receptor-specific lipid transfer mediated by its extracellular domain. J Biol Chem 1998, 273:26338-26348.

91. Stangl H, Hyatt M, Hobbs HH: Transport of lipids from high and low density lipoproteins via scavenger receptor-BI. J Biol Chem 1999, 274:32692-32698.

92. Swarnakar S, Temel RE, Connelly MA, Azhar S, Williams DL: Scavenger receptor class $B$, type I, mediates selective uptake of low density lipoprotein cholesteryl ester. J Biol Chem 1999, 274:29733-29739.

93. Graf GA, Connell PM, Westhuyzen DR van der, Smart EJ: The class $B$, type I scavenger receptor promotes the selective uptake of high density lipoprotein cholesterol ethers into caveolae. J Biol Chem 1999, 274: I 2043-I 2048.

94. Gu X, Kozarsky K, Krieger M: Scavenger receptor class B, type I-mediated $[3 \mathrm{H}]$ cholesterol efflux to high and low density lipoproteins is dependent on lipoprotein binding to the receptor. J Biol Chem 2000, 275:29993-3000I.

95. Silver DL, Wang N, Xiao X, Tall AR: High density lipoprotein (HDL) particle uptake mediated by scavenger receptor class $B$ type I results in selective sorting of HDL cholesterol from protein and polarized cholesterol secretion. J Biol Chem 200I, 276:25287-25293.

96. Rigotti A, Trigatti BL, Penman M, Rayburn H, Herz J, Krieger M: A targeted mutation in the murine gene encoding the high density lipoprotein (HDL) receptor scavenger receptor class B type I reveals its key role in HDL metabolism. Proc Natl Acad Sci USA 1997, 94:12610-12615.

97. Varban ML, Rinninger F, Wang N, Fairchild-Huntress V, Dunmore JH, Fang Q, Gosselin ML, Dixon KL, Deeds JD, Acton SL, Tall AR, Huszar $D$ : Targeted mutation reveals a central role for SR-BI in hepatic selective uptake of high density lipoprotein cholesterol. Proc Natl Acad Sci USA 1998, 95:461 9-4624.

98. Wang N, Arai T, Ji Y, Rinninger F, Tall AR: Liver-specific overexpression of scavenger receptor $B I$ decreases levels of very low density lipoprotein ApoB, low density lipoprotein ApoB, and high density lipoprotein in transgenic mice. J Biol Chem 1998, 273:32920-32926.

99. Catanese MT, Graziani R, von Hahn T, Moreau M, Huby T, Paonessa G, Santini C, Luzzago A, Rice CM, Cortese R, Vitelli A, Nicosia A: High-avidity monoclonal antibodies against the human scavenger class B type I receptor efficiently block hepatitis C virus infection in the presence of high-density lipoprotein. Virol 2007, 8I:8063-807!.

100. Aizaki H, Morikawa K, Fukasawa M, Hara H, Inoue Y, Tani H, Saito K, Nishijima M, Hanada K, Matsuura Y, Lai MM, Miyamura T, Wakita T, Suzuki T: Critical role of virion-associated cholesterol and sphingolipid in hepatitis C virus infection. J Virol 2008, 82:5715-5724.

10I. Hewitt KJ, Agarwal R, Morin PJ: The claudin gene family: expression in normal and neoplastic tissues. BMC Cancer 2006, 6: 186 .

102. Wen H, Watry DD, Marcondes MC, Fox HS: Selective decrease in paracellular conductance of tight junctions: role of the first extracellular domain of claudin-5. Mol Cell Biol 2004, 24:8408-84I7.

103. Krause G, Winkler L, Mueller SL, Haseloff RF, Piontek J, Blasig IE: Structure and function of claudins. Biochim Biophys Acta 2008 1778:631-645.

104. Furuse M, Hata M, Furuse K, Yoshida Y, Haratake A, Sugitani Y, Noda T, Kubo A, Tsukita S: Claudin-based tight junctions are crucial 
for the mammalian epidermal barrier: a lesson from claudinI-deficient mice. J Cell Biol 2002, I56:1099-I III.

105. Nitta T, Hata M, Gotoh S, Seo Y, Sasaki H, Hashimoto N, Furuse M, Tsukita S: Size-selective loosening of the blood-brain barrier in claudin-5-deficient mice. J Cell Biol 2003, 161:653-660.

106. Gow A, Southwood CM, Li JS, Pariali M, Riordan GP, Brodie SE, Danias J, Bronstein JM, Kachar B, Lazzarini RA: CNS myelin and sertoli cell tight junction strands are absent in Osp/claudinI I null mice. Cell 1999, 99:649-659.

107. Ben-Yosef T, Belyantseva IA, Saunders TL, Hughes ED, Kawamoto K, Van Itallie CM, Beyer LA, Halsey K, Gardner DJ, Wilcox ER, Rasmussen J, Anderson JM, Dolan DF, Forge A, Raphael Y, Camper SA, Friedman TB: Claudin 14 knockout mice, a model for autosomal recessive deafness DFNB29, are deaf due to cochlear hair cell degeneration. Hum Mol Genet 2003, I 2:2049-206 I.

108. Ikenouchi J, Furuse M, Furuse K, Sasaki H, Tsukita S, Tsukita S: Tricellulin constitutes a novel barrier at tricellular contacts of epithelial cells. J Cell Biol 2005, 1 7 I:939-945.

109. Yu AS: Claudins and epithelial paracellular transport: the end of the beginning. Curr Opin Nephrol Hypertens 2003, I 2:503-509.

1 10. Furuse M, Fujita K, Hiiragi T, Fujimoto K, Tsukita S: Claudin-I and 2: novel integral membrane proteins localizing at tight junctions with no sequence similarity to occludin. J Cell Biol 1998, | 41: I539-I550.

III. Evans MJ, von Hahn T, Tscherne DM, Syder AJ, Panis M, Wolk B, Hatziioannou T, McKeating JA, Bieniasz PD, Rice CM: Claudin-I is a hepatitis $C$ virus co-receptor required for a late step in entry. Nature 2007, 446:80I-805.

1 12. Zheng A, Yuan F, Li Y, Zhu F, Hou P, Li J, Song X, Ding M, Deng H: Claudin- 6 and claudin-9 function as additional coreceptors for hepatitis C virus. J Virol 2007, 8 I: 12465-1247I.

1 13. Meertens L, Bertaux C, Cukierman L, Cormier E, Lavillette D, Cosset FL, Dragic T: The tight junction proteins claudin- I, -6, and -9 are entry cofactors for hepatitis C virus. J Virol 2008, 82:3555-3560.

114. Davis CG, van Driel IR, Russell DW, Brown MS, Goldstein JL: The low density lipoprotein receptor. Identification of amino acids in cytoplasmic domain required for rapid endocytosis. J Biol Chem 1987, 262:4075-4082.

115. Lehrman MA, Goldstein JL, Brown MS, Russell DW, Schneider WJ: Internalization-defective LDL receptors produced by genes with nonsense and frameshift mutations that truncate the cytoplasmic domain. Cell 1985, 41:735-743.

1 16. Beglova N, Blacklow SC: The LDL receptor: how acid pulls the trigger. Trends Biochem Sci 2005, 30:309-317.

117. Russell DW, Brown MS, Goldstein JL: Different combinations of cysteine-rich repeats mediate binding of low density lipoprotein receptor to two different proteins. I Biol Chem 1989, 264:21682-21688.

1 18. Brown MS, Goldstein JL: Familial hypercholesterolemia: defective binding of lipoproteins to cultured fibroblasts associated with impaired regulation of 3-hydroxy-3-methylglutaryl coenzyme A reductase activity. Proc Natl Acad Sci USA 1974, 71:788-792.

119. Innerarity TL, Mahley RW: Enhanced binding by cultured human fibroblasts of apo-E-containing lipoproteins as compared with low density lipoproteins. Biochemistry 1978, 17:1440-I447.

120. Innerarity TL, Pitas RE, Mahley RW: Binding of arginine-rich (E) apoprotein after recombination with phospholipid vesicles to the low density lipoprotein receptors of fibroblasts. J Biol Chem 1979, 254:4186-4190.

121. Brown MS, Goldstein JL: A receptor-mediated pathway for cholesterol homeostasis. Science 1986, 232:34-47.

122. Bernfield M, Gotte M, Park PW, Reizes O, Fitzgerald ML, Lincecum J, Zako M: Functions of cell surface heparan sulfate proteoglycans. Annu Rev Biochem 1999, 68:729-777.

123. Esko JD, Lindahl U: Molecular diversity of heparan sulfate. J Clin Invest 200I, 108:169-173.

124. Ploss A, Evans MJ, Gaysinskaya VA, Panis M, You H, de Jong YP, Rice $C M$ : Human occludin is a hepatitis $C$ virus entry factor required for infection of mouse cells. Nature 2009, 457:882-886.

125. Reynolds GM, Harris HJ, Jennings A, Hu K, Grove J, Lalor PF, Adams DH, Balfe P, Hubscher SG, McKeating JA: Hepatitis C virus receptor expression in normal and diseased liver tissue. Hepatology 2008, 47:418-427.
Publish with Biomed Central and every scientist can read your work free of charge

"BioMed Central will be the most significant development for disseminating the results of biomedical research in our lifetime. "

Sir Paul Nurse, Cancer Research UK

Your research papers will be:

- available free of charge to the entire biomedical community

- peer reviewed and published immediately upon acceptance

- cited in PubMed and archived on PubMed Central

- yours - you keep the copyright

Submit your manuscript here:

http://www.biomedcentral.com/info/publishing_adv.asp 